Piotr MaśLOCH

Wyższa Szkoła Bankowa, Toruń, Polska

\title{
Globalizacja i rozwój gospodarki w warunkach kryzysu
}

\section{Globalization and Market Development in Crisis}

Streszczenie: Zachwyt nad globalizacją oraz próba zastanowienia się, czy globalizację nadal należy traktować jako metodę rozwiązywania wszelkich problemów społecznych. Zwycięstwo globalnej gospodarki rynkowej i samoregulacja gospodarki globalnej. Przyczyny i skutki współczesnych procesów globalizacyjnych, stanowiących szanse rozwoju dla jednych oraz zagrożenia dla innych (zarówno całych gospodarek, jak i poszczególnych przedsiębiorstw). I wreszcie problem najistotniejszy: globalizacja a ogólnoświatowe kryzysy gospodarcze. Wymienione zagadnienia dotyczące związków korelacyjnych pomiędzy współczesną globalizacją a przyczynami kryzysów w gospodarce światowej stanowią temat niniejszego artykułu.

Abstract: Admiration for globalization. Globalization as a method of solving all social problems. Victory of the global market economy and self-control of the global economy. These such serious problems concerning the correlation between modern globalization and an economy in crisis are leading contents of this article. It shows the nature of modern globalization with a detailed analysis, which presents in what way these phenomena influence changes in the global economy and global crisis.

Słowa kluczowe: globalizacja, kryzys, rynek, gospodarka

Key words: globalization, crisis, market, economy

\section{WSTĘP}

Globalizacja jako metoda rozwiązywania wszelkich problemów społecznych, zwycięstwo globalnej gospodarki rynkowej i samoregulacja gospodarki globalnej - te jakże ważne tezy głoszone dotychczas są obecnie dyskutowane, podawane w wątpliwość. Na naszych oczach dokonują się procesy, o których jeszcze kilka lat temu nikt by nie pomyślał. Iluż to najwybitniejszych ekonomistów przeceniło cudowną samoregulację rynku? Dynamiczny rozwój gospodarki globalnej w powiązaniu z coraz głębszymi kryzysami gospodarczymi zmuszają 
do zadawania pytań na temat przyczyn i ewentualnych następstw takiej sytuacji. Zmuszają do refleksji: gdzie podziała się tzw. niewidzialna ręka rynku, panaceum na wszelkie problemy gospodarcze?

\section{ISTOTA WSPÓŁCZESNEJ GLOBALIZACJI}

Pojęcie globalizacji nie jest jednoznacznie sprecyzowane, o czym najlepiej świadczy przykład dwóch jego różnych znaczeń. Z jednej strony termin „globalny” używany jest tylko do opisu tych firm, które realizują standardowe strategie na wszystkich rynkach świata, z drugiej strony do opisu każdej firmy podejmującej ekspansję poza swój rynek wewnętrzny. $\mathrm{W}$ pierwszym wypadku termin ten jest używany w zbyt wąskim znaczeniu, w drugim jest mylony z procesem „stawania się międzynarodowym” (Kornacka, 2000: 25). Zastanawiając się nad pojęciem globalizacji, warto przytoczyć definicję zaprezentowaną przez B. Liberską. Jej zdaniem:

globalizację ekonomiczną definiuje się jako postępujący proces integrowania się krajowych i regionalnych rynków w jeden globalny rynek towarów, usług i kapitału. Proces ten prowadzi do rosnącego przenikania i scalania się rynków oraz umiędzynarodowienia produkcji, dystrybucji, marketingu i przyjęcia przez firmy globalnych strategii działania (Liberska, 2002: 17).

W niektórych opracowaniach fachowych globalizację traktuje się jako zespół procesów prowadzących do ,intensyfikacji ekonomicznych, politycznych i kulturowych stosunków poprzez granice" (Liberska, 2002: 17). Globalizację należy zatem - zgodnie z tymi poglądami - traktować w sposób całościowy oraz próbować wskazać na podstawowe jej implikacje.

Ze względu na brak jednoznacznej definicji globalizacja może być traktowana bardzo różnie lub zgodnie z ocenami ideologicznymi definiującego. Na ogół jednak chodzi tu o pewne uwarunkowania procesu traktowane w miarę możliwości równorzędnie. Należą do nich: ogólnoświatowa skala, waga i sposób rozwiązywania problemów wpływających w mniejszym lub większym stopniu na rozwój wszystkich społeczeństw, możliwych do pokonania jedynie przy lepszej, szerokiej i wielopłaszczyznowej współpracy wszystkich stron.

Równie interesujące podejście do problemu właściwego zdefiniowania terminu ,globalizacja" reprezentuje Anna Zorska, twierdząc, że pojęciem tym określamy znaczące i złożone procesy zachodzące obecnie w skali ogólnoświatowej (Zorska, 1998: 13). Autorka ta potwierdza, że pomimo szerokiej dyskusji na temat różnorodnych przejawów i aspektów globalizacji nie ma teorii, a nawet jednej, szeroko rozumianej definicji tego procesu. Wiadomo jednak, że dokonują się one w różnych dziedzinach: ekonomicznej, technicznej, socjologicznej, kulturowej. Twierdzi się nawet, iż największy postęp globalizacji dokonał się dotychczas w sferze ekonomicznej, za jego główną konsekwencję uznano zaś stopniowe tworzenie się gospodarki ogólnoświatowej.

Termin „globalizacja” nie był dotychczas obecny w słownikach wyrazów obcych, ale z wyjaśnienia słowa ,globalny” wnioskujemy, że jego istotą jest ogólnoświatowy charakter 
i zakres określanych przez nie kategorii. W sensie ogólnym globalizacja jest procesem następującym na skutek zjawisk o charakterze ogólnoświatowym. W ujęciu ekonomicznym natomiast globalizacja i globalizowanie najczęściej odnoszą się do działalności gospodarczej, gospodarki, rynków branżowych, poszczególnych gałęzi gospodarki, przedsiębiorstw czy też upodobań konsumentów. Mogą być również ściśle związane z procesami narastającej integracji gospodarek międzynarodowych przez, między innymi, handel międzynarodowy. W miarę jak kapitał staje się coraz bardziej mobilny, a nowe technologie ułatwiają komunikowanie się, granice poszczególnych państw ulegają zatarciu i stają się coraz bardziej dostępne dla działalności gospodarczej realizowanej w skali międzynarodowej.

Analizując zaproponowane dotychczas definicje, można zauważyć, że w sposób niezwykle trafny akcentują one mnogość, rozległość, siłę i wzajemność powiązań społeczeństw na etapie globalizacji. Definicje te - co jest niezwykle istotne - zachowują pełną użyteczność w odniesieniu do sfery ekonomicznej, w tym do procesów charakterystycznych dla współczesnej gospodarki o charakterze globalnym.

Warto podkreślić, że w przedstawionej definicji stwierdza się istnienie pewnych cech procesu globalizacji, natomiast w niewielkim stopniu zaakcentowano dynamiczny jego charakter. Wynika on z dwóch przyczyn: po pierwsze, należy modyfikować istniejące oraz tworzyć nowe powiązania i zależności w systemie światowym; po drugie, dokonujące się długofalowo zmiany w potencjale i układzie elementów światowego systemu z upływem czasu implikują zmiany jego funkcjonowania. Wewnętrzna dynamika procesu globalizacji może zatem w istotny sposób kształtować jego ogólny przebieg, a w konsekwencji modyfikować strukturę oraz funkcjonowanie gospodarki światowej.

Analizując pojęcie globalizacji, trzeba zwrócić uwagę między innymi na rynek konsumenta, który swoim zasięgiem obejmuje cały świat, w związku z czym następuje coraz szybsza internacjonalizacja wielu przedsiębiorstw narodowych. Nawet rdzenne przedsiębiorstwa amerykańskie, koncentrujące się do niedawna na bardzo chłonnym rynku amerykańskim, uzyskują znaczną część dochodów ze sprzedaży swoich dóbr i usług na rynkach międzynarodowych. Na rynku globalnym zatracają też stopniowo swój charakter narodowy poszczególne produkty (Gwiazda, 1999: 22).

Globalizacja, jak wynika z dotychczasowych rozważań, jest procesem dynamicznym, dlatego jej stopień i przebieg może się zmieniać w różnych dziedzinach, może dotyczyć zarówno rynków towarowych, jak i rynków usług, produkcji, przemysłu, technologii i wiedzy, a także wzorców konsumpcji oraz kultury masowej.

Spór wokół globalizacji dotyczy jednak nie tyle jej domniemanej genezy, ile wskaźników natężenia i zakresu całego procesu. W tej kwestii panuje zgoda, że druga połowa XX wieku i początek wieku XXI to okres niezwykłego przyspieszenia. Globalizację często utożsamia się błędnie z homogenizacją, odnosząc ten proces głównie do sfery konsumpcji i kultury. Globalizacja i homogenizacja stają się w tym ujęciu synonimami określającymi zjawisko zdominowania ludzkiej świadomości przez elektroniczne środki masowego przekazu, które ujednolicają zarówno treści kulturowe, będące w powszechnym obiegu, jak i sposób ich odbioru. W najszerszym rozumieniu globalizacja oznacza, że zjawiska regionalne, pozostające nadal w realnym oddaleniu geograficznym, mają swoje odpowiedniki 
w innej części globu. W tym sensie chodzi o ponadnarodowy charakter procesów ekonomicznych i kulturowo-społecznych. Wprawdzie świat nadal dzieli się na terytoria narodowe i odrębne państwa, coraz więcej zjawisk społecznych, ekonomicznych, kulturowych i demograficznych w ich obrębie przekracza jednak tradycyjnie rozumiane granice narodowe i państwowe. Współcześnie mamy do czynienia z niebywałą intensyfikacją relacji społecznych na skalę światową, dzięki której zjawiska regionalne wiążą się ze sobą, mają swoje odpowiedniki w różnych częściach globu, a rozwój w każdym zakątku świata musi być rozumiany jako rozpowszechnianie się uczestnictwa w zjawiskach globalnych. Procesy globalne są niezależne od konkretnych terytoriów narodowych i zachodzą w przestrzeni ponadlokalnej, podczas gdy zjawiska międzykulturowe występują (przynajmniej początkowo) w pewnym kontekście narodowym i dopiero później go przekraczają.

Współcześnie bardzo trudno odróżnić zjawisko lokalne od globalnego, gdyż oba te wymiary nieustannie się przenikają i wymagają łącznego traktowania. W wyniku nieustannego przemieszczania się ludzi oraz ujednolicania modelu konsumpcji tworzą się także szczególne miejsca w skali globu, mające wszędzie identyczne parametry, a nazywane hiperprzestrzeniami: lotniska, sieci standardowych restauracji i barów, supermarkety, sklepy muzyczne to miejsca, w których ludzie stają się jednostkami bez jakichkolwiek odniesień kulturowych.

Globalizacja jest więc faktem, a o jej istocie decyduje swoiste kurczenie się świata, zanikanie granic i podziałów narodowych. O istocie procesu stanowi jeszcze jedno, bardzo ważne zjawisko - ujednolicanie produktów, kultur, rynków, w tym również (a może przede wszystkim) rozwój rynku globalnego.

\section{PRZYCZYNOWO-SKUTKOWY ASPEKT GLOBALIZACJI. \\ ROLA MEDIÓW W PROCESACH GLOBALIZACYJNYCH}

Globalizacja bywa określana jako niekończąca się podróż, której nieosiągalnym celem jest świat pozbawiony różnic. Niektórzy badacze tematu, jak na przykład Sylvia Ostry, nie znajdują żadnej odpowiedniej definicji, oceniając pojęcie jako niedefiniowalne, stosują termin „głębsza integracja”, który odnoszą do „procesu tworzenia się coraz ściślejszych związków między krajami, zachodzącego etapami od zakończenia drugiej wojny światowej” (Ostry, 2001: 45).

Analizę określenia ,globalizacja” warto również przeprowadzić w ujęciu przyczynowo-skutkowym, gdyż to właśnie zmiany technologiczne, rozwój społeczny, polityczny i ekonomiczny w ciągu ostatnich piętnastu-dwudziestu lat skierowały świat w kierunku tworzenia globalnej wioski lub jednoczącej się wspólnoty, czyli jednorodnego, zunifikowanego rynku globalnego, jeśli chodzi o gusty konsumentów i preferencje dotyczące produktów. Korzystają z tego głównie organizacje globalne wytwarzające i oferujące standaryzowane produkty i usługi w celu osiągnięcia ekonomii skali o światowym zasięgu (Stonehouse i in., 2001: 6). Warto w tym miejscu dodać, że niejednokrotnie w nauce pojawiały się głosy kwestionujące 
hipotezę globalizacji i potrzebę tworzenia standaryzowanych strategii i produktów globalnych. Argumentując istnienie barier standaryzacji produktów i strategii, dowodzono, że można osiągnąć dużo większe zyski przez przystosowanie produktów, produkcji i strategii do potrzeb poszczególnych rynków. Obecnie globalizacja i wszelkie procesy w związku z nią zachodzące przejawiają się w następujących aspektach: pojawienie się dwóch zasadniczych trendów globalizacji - trend związany z tworzeniem rynków globalnych oraz globalizacja działań dotyczących wartości dodanej. Można też mówić o zjawisku zwanym orientalnym wyzwaniem, polegającym na przypisaniu sukcesu japońskim firmom na rynkach światowych dzięki przyjęciu przez nie strategii globalnych wiążących koordynację i integrację w ogólnoświatowej produkcji i dystrybucji.

Najistotniejsze problemy uznawane za globalne, których nasilenie zagraża zdrowiu, życiu, a nawet upadkowi cywilizacji, to: wojna nuklearna, niekompetentne rozprzestrzenianie broni jądrowej, załamanie się równowagi ekologicznej, zmiany klimatyczne, klęska głodu, pogorszenie się sytuacji gospodarczej i społecznej najuboższych rejonów świata, terroryzm międzynarodowy. Obecnie, zgodnie z najnowszymi poglądami w tej dziedzinie, globalizacja postrzegana jest jako atrakcyjna, dająca szanse rozwoju idea, pozwalająca na rozwiązywanie problemów, które wymagają szerokiej współpracy międzynarodowej.

Niezmiernie istotną rolę w kształtowaniu obrazu świata jako globalnej wioski odgrywają nowoczesne media, dzięki którym dochodzi do kompresji relacji czasoprzestrzennych. Wzrastająca dostępność globalnej przestrzeni i współistnienie w czasie zjawisk ukazywanych przez media sprawiają, że idee dotyczące przestrzeni i czasu ulegają zniekształceniu i połączeniu. Międzynarodowy przepływ kapitału, pieniędzy, informacji i kultury niweczą linearną jedność obu tych wymiarów, powodując, że ulegają one skondensowaniu. Dawne peryferie i centra jawią się w mass mediach tak, jak gdyby były jednym miejscem, do którego można się udać bez przeszkód dzięki wyborowi odpowiedniego kanału. Świat multimedialny charakteryzuje się tym, że wszystkie wydarzenia, nawet te z najbardziej oddalonych rejonów świata, wydają się jednoczesne i namacalne.

Ważną rolę w utrwalaniu podobnego przekonania odgrywa Internet - w cybernetycznej sieci przestrzeń geograficzna i strefy czasowe ulegają całkowitej neutralizacji na rzecz zawartości informacyjnej przekazu, dostępnego w tym samym momencie na całym świecie. Teoretycy globalizacji podkreślają, że w przypadku tworzenia jednolitego rynku globalnego zjawisko to jest bardziej oczywiste i realne niż w ekonomii. Globalne zjawiska z tym związane można opisywać przez pryzmat pięciu wymiarów: medialnego, technologicznego, finansowego, ideologicznego i etnicznego. Wszystkie one, mimo dużego stopnia autonomiczności, są powiązane i przenikają się wzajemnie, składając się na współczesną gospodarkę o charakterze globalnym. 
GlobAliZACJA I JEJ ASPEKTY W ROZUMIENIU DYSTANSU KULTUROWEGO, ADMINISTRACYJNEGO, GEOGRAFICZNEGO I EKONOMICZNEGO

Globalizacja, jak można wnioskować z dotychczasowych rozważań, niesie ze sobą wspaniałe perspektywy rozwoju państw, gospodarek i rynków. Ale czy tak jest rzeczywiście? Większość współczesnych firm prawdopodobnie przecenia atrakcyjność rynków zagranicznych, co w rezultacie prowadzi do ogromnych kosztów błędnych decyzji. Większość z nich wiąże się z odległością rozumianą w kilku podstawowych wymiarach, wśród których najistotniejsze są dystans: geograficzny, kulturowy, administracyjny, polityczny i ekonomiczny (Ghemawat, 2001: 6).

Obecnie, pomimo znacznego ujednolicenia świata spowodowanego rozwojem nowoczesnych technologii informacyjnych oraz komunikacji globalnej, nie można zapomnieć o odległości, która wciąż się liczy i aspekt ten musi być brany pod uwagę przez przedsiębiorstwa podejmujące decyzję o budowaniu globalnych rynków konsumenckich. Decyzja taka musi być poprzedzona analizą wymienionych powyżej wymiarów dystansu: kulturowego, administracyjnego, geograficznego i ekonomicznego (Maśloch, 2011: 20).

Dystans kulturowy - determinuje sposób wchodzenia ludzi i społeczeństw oraz przedsiębiorstw i instytucji we wzajemne interakcje. Pojawiające się różnice religijne, norm społecznych, rasowe i językowe powodują powstawanie dystansu pomiędzy poszczególnymi krajami, mając jednocześnie olbrzymi wpływ na wymianę handlową. Niektóre z atrybutów dystansu kulturowego są oczywiste, powszechnie akceptowane i zrozumiałe (różnice językowe). Wpływ innych, np. norm społecznych (niepisanych reguł sterujących zachowaniem jednostek), bywa często ukryty. Jednym z najbardziej widocznych przykładów jest tutaj rola norm religijnych przy wyborze produktów spożywczych.

Dystans administracyjny - obejmuje polityczne i historyczne związki pomiędzy krajami. Najlepszym przykładem będą tutaj preferencyjne umowy handlowe, wspólna waluta czy też unie polityczno-gospodarcze. Integracja, chociażby w ramach Unii Europejskiej, stanowi przykład działań zmierzających do zmniejszenia dystansu administracyjnego pomiędzy poszczególnymi krajami. Państwa mogą go kreować także przez realizację konkretnej polityki rządu, np. polityka ochrony środowiska, ustawy antykorupcyjne. Warto zauważyć ponadto, że część działań rządów poszczególnych państw ma na celu ochronę rodzimych producentów i ma szczególne zastosowanie wtedy, gdy chodzi o lidera narodowego ważnych gałęzi strategicznych, kluczowych dla bezpieczeństwa narodowego.

Dystans geograficzny - omawiając ten aspekt odległości, można sformułować bardzo prostą zasadę: im dalej firma znajduje się od kraju docelowego, tym trudniej jest jej prowadzić działalność. Dystans geograficzny to jednak nie tylko tradycyjnie rozumiana odległość w kilometrach. Bardzo ważną cechą tego wymiaru odległości jest wielkość kraju docelowego, dostęp do morza i jego topografia. Liczy się ponadto sieć dróg i komunikacji oraz (a może przede wszystkim) infrastruktura telekomunikacyjna. Wymienione tu atrybuty określają przede wszystkim koszty transportu dóbr i usług. Aspekt geograficzny ma ponadto niebagatelny wpływ na inwestycje bezpośrednie firm, określa koszty sieci informacyjnych i transportowych wewnątrz firm oraz koszty działań korporacji międzynarodowych. 
Dystans ekonomiczny - najważniejszy atrybut dystansu ekonomicznego - dobrobyt i poziom dochodów konsumentów - wpływa znacząco na poziom wymiany handlowej pomiędzy krajami oraz rodzaj partnerów, jakich firmy poszukują we współpracy międzynarodowej. Warto również zwrócić uwagę, że kraje bogate bardziej angażują się we współpracę ekonomiczną z krajami o podobnej pozycji ekonomicznej, ale i kraje biedniejsze wolą współpracować z bogatszymi państwami.

Jak wynika z powyższych charakterystyk, wpływ szeroko rozumianej odległości na działalność globalną organizacji jest ogromny. Menedżerowie, podejmując określone decyzje, muszą brać pod uwagę wszystkie jego wymiary, pamiętając, że dystans wciąż się liczy, zaś nowoczesne technologie zmniejszają, ale nie eliminują wszystkich kosztów odległości.

Analizując różne uwarunkowania globalizacji, warto zwrócić uwagę na paradoks epoki polegający na współwystępowaniu globalnych tendencji integrujących z tendencjami różnicującymi w postaci rosnącej nietolerancji kulturowej, etnicznej, religijnej i obywatelskiej, co $\mathrm{w}$ połączeniu z separatystycznymi dążeniami niektórych narodów prowadzi do dezintegracji i umacniania ich zaściankowości. Globalizacja z jednej strony uświadamia różnorodność kultur i wyostrza różnice dzielące poszczególne narody, z drugiej zaś prowadzi do ujednolicenia wartości. W tym momencie rodzi się pytanie o to, czy ujednolicanie wartości wynika z faktu mieszania się elementów poszczególnych kultur zgodnie z prawem każdego społeczeństwa do pielęgnowania i poszanowania własnych wartości, czy też główne centra ekonomiczne i polityczne świata, wykorzystując własną przewagę i ogromne możliwości lansowania swoich wzorców, narzucą je reszcie świata? (Kłosowska, 1997: 4-17). W tym ujęciu otoczenie społeczno-kulturowe stanowi jeden z najważniejszych czynników warunkujących proces globalizacji. Pewne wartości mają bowiem charakter stały i wywierają duży wpływ zarówno na zachowanie ludzi, jak i postrzeganie przez nich siebie, innych ludzi, instytucji, społeczeństwa, środowiska naturalnego i wszechświata (Kotler, 1994: 155-157). Wobec powyższego istotne staje się poznanie wartości uniwersalnych oraz lokalnych tradycji, zwyczajów i subkultur współistniejących w danym kraju. Najczęściej wymienia się obecnie osiem grup czynników warunkujących procesy globalizacji: język, religię, wartości i postawy, prawo, system oświaty, technologię i kulturę materialną, politykę oraz formy organizacji społecznej.

Równie istotnymi czynnikami wpływającymi na tworzenie jednolitego rynku globalnego są złożoność i zmienność jego otoczenia, zarówno krajowego, jak i międzynarodowego. Fakt ten wynika z coraz szybciej zacieśniającej się międzynarodowej współzależności ekonomicznej pomiędzy większością krajów świata oraz przenikania za pośrednictwem nowoczesnych mediów i upowszechniania się w wielu krajach różnych kultur, wzorców postępowania, stylów życia i konsumpcji. Przewiduje się nawet, że konsekwencją współczesnej globalizacji będzie ukształtowanie się otwartego dla wszystkich rynku globalnego (Baker, 1995: 13). Takie twierdzenie wydaje się ze wszech miar słuszne, ponieważ otwarciu rynku globalnego sprzyjają wszelkie nowe formy dystrybucji towarów i usług za pośrednictwem elektronicznych środków przekazu, podróże i migracje ludności oraz ekspansja firm ponadnarodowych. Otwarty dla wszystkich rynek globalny, na którym nie ma barier wejścia oraz innych uwarunkowań związanych z istnieniem państw narodowych, odrębnych regulacji 
prawnych i taryf celnych stworzyłby wręcz nieograniczone możliwości dokonywania najlepszych wyborów przez konsumentów z całego świata.

Globalizacja, jak twierdzi M. Strużycki, jest jednak przede wszystkim zjawiskiem o niezwykłej dynamice rozwojowej, odbieranym jako naturalny kierunek postępu w skali światowej. Nie jest to więc zjawisko wyłącznie o charakterze penetracyjnym, osłabiającym szanse wykorzystania krajowych kapitałów i lokalnych możliwości. Napływający z zewnątrz kapitał, związane z nim technologie i metody zarządzania kształtują nowy obraz ekonomiki kraju, wyznaczając nowe więzi o charakterze kapitałowym, marketingowym i innym. Globalizacja to proces wciąż trwający, którego rozwój w ujęciu historycznym na pewno jeszcze się nie skończył.

Analizując problemy globalizacji i historyczne kształtowanie się tego zjawiska nie sposób pominąć postaci Alvina Tofflera, który w wydanej w 1970 roku pracy Szok przyszłości pisał o rodzącym się pokoleniu koczowników, kreśląc wizje ludzi przyszłości, ludzi przenoszących się z miejsca na miejsce, których wykształcenie, wiedza i sprawność merytoryczna możliwa jest do wykorzystania w razie potrzeby w każdym państwie, w każdym regionie globu i na każdym kontynencie (Toffler, 1999: 45). W taki właśnie sposób należy rozumieć ewolucyjny charakter globalizacji - od prostych, starożytnych koncepcji począwszy, przez trendy XIX-wieczne, aż po koncepcje XXI wieku, epoki, w której przestają liczyć się religia, kultura i narodowość jako wyznaczniki zawodowej tożsamości. Czynniki te z pewnością wywarły ogromny wpływ na współczesne procesy globalizacyjne na świecie oraz na tworzenie się współczesnego rynku globalnego.

Do zasadniczych czynników globalizacji, poza dotychczas wymienionymi, należą te, które wynikają z procesów ekonomicznych, politycznych, technologicznych i społecznych zachodzących w gospodarce. Należy zwrócić uwagę, że niektóre gałęzie, rynki lub branże są bardziej podatne na globalizację, na początku bowiem niewiele sektorów ma charakter międzynarodowy czy też globalny. W tworzeniu strategii globalnej niezmiernie istotne jest zdiagnozowanie, kiedy warunki panujące w sektorze stwarzają okazję do zastosowania instrumentów strategii globalnej. Warunki te - zgodnie z podziałem zaproponowanym w literaturze przedmiotu - można podzielić na cztery grupy czynników (Strategor, 1995: 182). Należą do nich: czynniki rynkowe, czynniki kosztowe, działania rządów i konkurencja. Zestawienie czynników determinujących proces globalizacji przedstawiono na ryc. 1.

Czynniki rynkowe uzależnione będą od zachowań konsumentów, struktury kanałów dystrybucji oraz cech marketingu. Występujące obecnie trendy w procesach globalizacyjnych powodują upodabnianie się potrzeb klientów w różnych krajach. W istotny sposób rozwiną się globalni klienci i dystrybutorzy, natomiast transferowalny marketing to już obecnie fakt, co przejawia się w wielojęzyczności opisów i identyczności opakowań.

Czynniki kosztowe zależą przede wszystkim od ekonomicznych zachowań zarówno przedsiębiorstw, jak i konsumentów. Przedsiębiorstwa działające na rynku globalnym dążą do obniżenia kosztów przez: osiąganie korzyści skali, korzystanie z efektu doświadczenia, obniżkę kosztów transportu oraz zróżnicowania kosztowego krajów. Cechą charakterystyczną współczesnych procesów globalizacyjnych jest tendencja do znoszenia barier handlowych, co z kolei pozytywnie wpływa na zwiększanie koncentracji produkcji i osiąganie wyższych korzyści skali. 


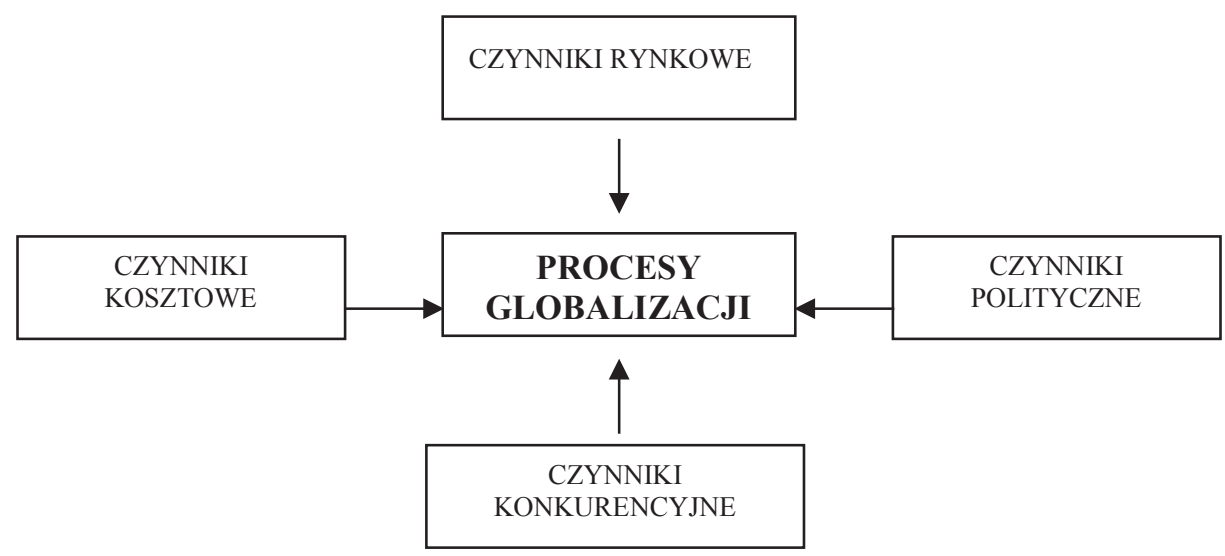

Ryc. 1. Czynniki procesów globalizacji

Źródło: opracowanie własne

Rządowe czynniki globalizacji zależeć będą od prawa ustanowionego przez rządy poszczególnych krajów. To właśnie od polityki realizowanej w poszczególnych państwach zależeć będą decyzje o przenoszeniu produkcji za granicę, otwieraniu nowych, zagranicznych oddziałów czy też szukaniu kolejnych rynków zbytu.

W syntetycznym i jednocześnie ciekawym ujęciu czynniki wpływające zarówno na rozwój procesów globalizacyjnych z jednej strony, jak i wyznaczające kierunek działalności przedsiębiorstwa z drugiej przedstawili T. Brake i D. Walker, grupując je w pięć kategorii (Brake, Walker, Walker, 1995: 4):

Konkurencja:

- silne bloki i porozumienia gospodarcze (np. Unia Europejska),

- pojawienie się i rozwój krajów nowo uprzemysłowionych,

- wzrost konkurencyjności,

- wzrost liczby zawieranych aliansów strategicznych.

Technologia:

- elastyczna produkcja i dystrybucja,

- skrócenie czasu wprowadzenia produkcji i dystrybucji produktu,

- nowe środki komunikacji

- rewolucja w informacji i komunikacji.

Rynki:

- zawężenie rynków krajowych,

- pojawienie się marek światowych.

Rząd:

- normy i standardy techniczne,

- polityka wolnego handlu,

- znoszenie barier taryfowych i pozataryfowych,

- deregulacja i liberalizacja przepisów, ograniczenie roli rządów, prywatyzacja. 
Klienci:

- rosnące wymagania w zakresie jakości, ceny,

- wzrastająca rola usług posprzedażnych.

Warto zauważyć, że konkurencyjne czynniki globalizacji w znacznym stopniu zależne są od zachowań konkurentów oraz od stopnia ostrości walki konkurencyjnej. Takie czynniki, jak: coraz większa wymiana międzynarodowa, rosnąca współzależność gospodarek krajów i pojawianie się nowych konkurentów zwiększają potencjał globalizacyjny sektora.

\section{SKUTKI GLOBALIZACJI I JEJ ZNACZENIE DLA ROZWOJU GOSPODARKI} W WARUNKACH KRYZYSU

Analizę wpływu, jaki globalizacja wywiera na gospodarkę światową, należy rozpocząć od krajów najbogatszych, które nadawały ton światu zachodniemu. Najłatwiej zauważalnym skutkiem globalizacji jest prawdopodobnie wciąż postępujący wzrost rozpiętości dochodowych między krajami zamożnymi i biednymi.

Według badań pochodzących z począatku XIX wieku i przeprowadzonych przez A. Madisona różnice dochodowe per capita krajów zamożnych i biednych przekraczały nieco tylko relację. Przez cały wiek XIX różnice te wzrastały, ale prawdziwe przyspieszenie nastąpiło w okresie ostatniego czterdziestolecia. Wiele krajów tzw. Trzeciego Świata przeżywa stagnację lub regres, co nader często skutkuje prawdziwym ubóstwem. Wszystkim tym zjawiskom towarzyszy obojętność krajów zamożnych. W latach 50. i 60. XX w. ONZ uchwalił postulat przeznaczania $1 \%$ PKB na pomoc dla Trzeciego Świata. Najdłużej rezolucję tę respektowały kraje nordyckie, obecnie jednak na te cele przeznacza się coraz niższe kwoty.

Wydaje się, że jednym ze sposobów zmniejszenia skali istniejących dysproporcji jest zwiększenie liczby inwestycji bezpośrednich w krajach rozwijających się. Niestety, pogląd o rosnącym poziomie inwestycji bezpośrednich w tych krajach to tylko złudne rozwiązanie problemu z dwóch powodów (Liberska, 2002: 287): inwestycje omijają kraje najbiedniejsze (tylko 12 zamożniejszych wśród biednych krajów przyciąga ok. 80\% wszystkich inwestycji napływających do Trzeciego Świata), ogromne zadłużenie dużej części krajów Trzeciego Świata sprawia, że odpływ kapitału w postaci odsetek i rat jest większy niż przypływ pomocy oraz inwestycji zagranicznych razem.

Analizując nierówności dochodów w poszczególnych grupach krajów, trzeba zwrócić uwagę na kolejną, powoli kształtującą się cechę mogącą warunkować dalszy przebieg globalizacji rynków konsumenckich. Chodzi mianowicie o fakt, że nie można dostrzec wyraźnego wzrostu nierówności w krajach afrykańskich czy azjatyckich. Jedyny kontynent, gdzie ta tendencja jest dominująca, to Ameryka Łacińska. Można zatem sądzić, że tendencje takie wynikają z większej siły procesów globalizacji na tym terenie oraz z większej podatności na wpływy północnoamerykańskie. 
Zastanawiając się nad cechami globalizacji, należy zwrócić uwagę na sposób ich scharakteryzowania przedstawiony przez Grzegorza Kołodko. Twierdzi on, że współczesna globalizacja stosunków ekonomicznych występująca z jednej strony oraz narastająca dysproporcja w podziale dochodów z drugiej strony zmuszają do formułowania poglądów o związkach przyczynowo-skutkowych występujących pomiędzy tymi zjawiskami (Kołodko, 2001: 341). Współcześni ekonomiści uznają, że zbyt daleko posunięte nierówności w zakresie dochodów są nie tylko niesprawiedliwe, ale przede wszystkim obracają się przeciwko efektywności alokacyjnej i osłabiają skłonność do oszczędzania, a tym samym do formowania kapitału. Dzisiejsze procesy globalizacji - pomimo szeregu wyraźnych korzyści - wciąż wywołują szereg napięć i protestów. Wymierzone są one przeciwko organizacjom postrzeganym jako siła napędowa globalizacji, którą z kolei wini się - chyba niesłusznie - za nierówności, a te z kolei są dla wielu ludzi tożsame z niesprawiedliwością, czyli nie zyskują aprobaty. Czy zatem odpowiedź na pytanie, w jakiej skali narasta nierówność i co ją powoduje, nie będzie jednocześnie próbą opisania skutków globalizacji? Odpowiedź wydaje się oczywista, przy czym należy zastanowić się właśnie nad przyczynami owej nierówności.

Po pierwsze, narastanie nierówności w stosunkach podziału jest faktem. O ile przez wieki ludzkość starała się walczyć z niesprawiedliwością, o tyle wiekowy postęp ekonomiczny prowadził tylko do pogłębiania dysproporcji. Na przykład w roku 1870 przeciętny dochód w krajach najbogatszych w porównaniu z przeciętnym dochodem krajów najbiedniejszych był 11 razy większy, a trzy pokolenia później wskaźnik ten był 39 razy większy. Jeszcze jedno pokolenie później - w roku 1985 - wielokrotność ta wynosiła 52 i - jak się szacuje obecnie zbliża się do 60 .

Po drugie, szczególnie uderzające jest narastanie nierówności podczas ostatnich dekad, przede wszystkim w latach 80. i 90. XX w., kiedy współczesna globalizacja oraz tzw. czwarta rewolucja techniczna nabrały wielkiego impetu. Coraz szybsze rozprzestrzenianie się kapitalistycznych stosunków produkcji na skalę globalną musi wpłynąć na zróżnicowanie dochodów. Globalizacja zwiększa więc obszar przedsiębiorczości, a to z kolei pociąga za sobą szybszy wzrost dochodów bardziej aktywnych grup społecznych.

Po trzecie, wyróżniamy wiele miar nierówności - o jaką zatem nierówność chodzi w globalnej gospodarce? Obecnie możemy wyodrębnić trzy jej wymiary: pierwszy to nierówność dochodowa w kraju. Narosła ona w wielu państwach, ale prawie wszędzie ma związek z otwieraniem się na zewnątrz. Drugi wymiar stanowi nierówność pomiędzy przeciętnymi dochodami poszczególnych krajów. Jeżeli PKB w jednym kraju rośnie szybciej niż w innych, wówczas pojawia się skłonność do obarczania odpowiedzialnością globalizacji. Trzeci wymiar dotyczy zróżnicowania pomiędzy dochodami wszystkich mieszkańców Ziemi. Jest ono ogromne i ciągle rośnie.

Globalizacja nie sprzyja raczej w tym ujęciu wyrównywaniu warunków życia ludzi na świecie. Oprócz inwestorów tylko wysokiej klasy specjaliści mają możliwości poruszania się po rynku globalnym. I jest to zasadnicza cecha odróżniająca tę grupę ludzi od pozostałej reszty ludności przywiązanej do swojego miejsca zamieszkania.

Warto w tym momencie zwrócić uwagę na dość charakterystyczne zjawisko: z jednej strony w globalnym świecie usuwane są ostatnie bariery hamujące swobodny przepływ 
towarów i kapitałów, z drugiej natomiast poszczególne państwa tworzą nowe bariery i umacniają stare, które mają uszczelnić granice państw przed migracjami ludzi najgorzej wykształconych i pozbawionych w swoich krajach perspektyw życiowych.

Dokonując analizy cech współczesnej globalizacji, należy stwierdzić, że do podstawowych przyczyn ogólnoświatowego kryzysu gospodarczego zalicza się obecnie (Kaczmarek, 2009: 172):

- bezpieczeństwo dostaw surowców dla przemysłu globalnego,

- zagrożenie globalnym terroryzmem,

- dolar amerykański i deficyt Stanów Zjednoczonych,

- w przypadku Chin ryzyko zbyt szybkiego wzrostu gospodarczego,

- konflikty polityczne i regionalne kryzysy gospodarcze,

- kryzys Światowej Organizacji Handlu.

Do najpoważniejszych przyczyn kryzysu gospodarczego ostatnich lat zalicza się sytuację gospodarczą w Stanach Zjednoczonych. Wyróżnić można tutaj dwie grupy czynników - pierwsza to tzw. przyczyny zewnętrzne, głównie załamanie na amerykańskim rynku kredytów hipotecznych w 2007 roku oraz rosnąca podaż pieniądza spowodowana brakiem nadzoru nad rynkami finansowymi. Drugą grupę stanowią czynniki wewnętrzne, między innymi wzrost zadłużenia USA na arenie międzynarodowej, powiązane z szybko rosnącym ujemnym deficytem handlowym (głównie w stosunku do Chin).

W sytuacji gdy kryzys gospodarczy dotyka mocarstwo, zwykle szybko rozprzestrzenia się na gospodarki innych państw. Tak było w przypadku Wielkiego Kryzysu Gospodarczego z lat 30. ubiegłego wieku, podobnie jest obecnie. Recesja gospodarcza dotarła do Europy, powodując kryzys wielu państw Starego Kontynentu. Nie jest jednak dziełem przypadku, że najbardziej boleśnie dotknął kraje europejskie. Rozbudowane systemy świadczeń socjalnych, zadłużenie państw, biurokracja, korupcja, brak odpowiednich inwestycji oraz koniecznych reform, niekontrolowany rozwój instytucji finansowych - to tylko niektóre przyczyny, recesji gospodarczej na południu naszego kontynentu. Kolejną przyczyną były wieloletnie, nieodpowiedzialne rządy polityków, którzy składali społeczeństwu coraz mniej realne obietnice, zmniejszając np. liczbę godzin pracy, podnosząc pensję minimalną, gwarantując coraz szersze świadczenia socjalne czy wprowadzając wcześniejszy wiek emerytalny.

Obecnie niezwykle trudno jest określić, jakie będą skutki trwającego kryzysu gospodarczego. Do najistotniejszych zaliczyć można takie czynniki, jak: obniżenie Produktu Krajowego Brutto, spadek produkcji przemysłowej do poziomu z lat 90. XX w., ponad $10 \%$ bezrobocie, dług publiczny przekraczający $80 \%$ oraz ponad $7 \%$ deficyt budżetowy. Wszystkie te dane dotyczą ogólnie całej Unii Europejskiej. Należy jednak podkreślić, że sytuacja Niemiec czy Austrii z około 5\% bezrobociem z jednej strony, a z drugiej Grecji czy Hiszpanii, gdzie bez pracy pozostaje prawie co czwarty obywatel, jest diametralnie różna. Wydaje się, że Polska jeszcze nie odczuła skutków omawianej sytuacji kryzysowej, choć patrząc na statystykę bezrobocia, które od kilkunastu lat wynosi w naszym kraju 10\%, można stwierdzić, że jest on dotknięty permanentnym kryzysem. 


\section{ZAKOŃCZENIE}

Zastanawiając się na złożonością procesu globalizacji oraz jej rezultatami, warto podkreślić, że to właśnie globalizacja stanowi silny czynnik przemian i jest poważnym wyzwaniem dla gospodarek, firm, instytucji, państw i całego porządku światowego.

Obecnie wyróżnia się cztery główne aspekty globalizacji:

- presja globalnych rynków finansowych (niestabilność, efekt domina),

- presja konkurencji globalnej,

- globalizacja produkcji i działalności gospodarczej (międzynarodowych sieci produkcji korporacji transnarodowych),

- infrastruktura globalizacyjna (rynki, instytucje, regulacje).

Globalizacja niesie ze sobą nowe wyzwania i powoduje określone konsekwencje, na które muszą zareagować przede wszystkim rynki i przedsiębiorstwa, przyjmując strategie zapewniające im dynamiczny rozwój. Odpowiednich procesów dostosowawczych wymagają również różnego rodzaju instytucje na szczeblu zarówno krajowym, regionalnym i międzynarodowym. Należy podkreślić, że współczesne oddziaływanie globalizacji na gospodarki państw i regionów jest zróżnicowane i wynika - co zostało zasygnalizowane w artykule - ze złożoności i wielowątkowości omawianego procesu. Równie ważnym zagadnieniem, wymagającym dalszych, pogłębionych badań i analiz, jest wpływ globalizacji na rozwój kryzysu ogólnoświatowego. Nasuwa się też pytanie, jak kryzys wpływa (hamująco, rozwojowo) właśnie na procesy globalizacji i internacjonalizacji. Wydaje się, że trudno sformułować tutaj jednoznaczne wnioski, natomiast przejawy i cechy tak rozumianej globalizacji będą długo jeszcze wyznaczać kierunek rozwoju współczesnych i przyszłych gospodarek państw i narodów.

\section{Literatura}

Baker, T.H. (1995). The Consumer in the Global Market. The OECD Observer, 192.

Brake, T. Walker, D., Walker, T. (1995). Doing Business Internationally. The Workbook to Cross Cultural Success. Princeton, New Yersey: Training Management Corporation.

Ghemawat, P. (2009). Distance Still Matters - the Hard Reality of Global Expansion. Harvard Business Review, 79(8), 137-147)

Gwiazda, A. (1999). Globalizacja i regionalizacja gospodarki światowej. Toruń: Wydawnictwo Adam Marszałek.

Kłosowska, A. (1997). Kultury narodowe wobec globalizacji a tożsamość jednostki. Kultura i Spoteczeństwo, 4.

Kaczmarek, T.T. (2009). Globalna gospodarka i globalny kryzys. Warszawa: Wydawnictwo Difin.

Kołodko, G. (2001). Moja globalizacja, czyli dookoła świata i z powrotem. Toruń: Dom Organizatora TNOIK.

Kornacka, D. (2000). Globalizacja - implikacje dla przedsiębiorstw. Szczecin: Wydawnictwo Uniwersytetu Szczecińskiego.

Kotler, P. (1994). Marketing. Warszawa: Wydawnictwo PWN. 
Kowalik, T. (2002). Kapitał globalny a tendencje egalitarne i antyegalitarne. W: B. Liberska (red.), Globalizacja. Mechanizmy i wyzwania. Warszawa: Wydawnictwo PWE.

Liberska, B. (red.), (2002). Globalizacja. Mechanizmy i wyzwania, Warszawa: Wydawnictwo PWE.

Maśloch, P. (2011). Restrukturyzacja przedsiębiorstw w Polsce $w$ dobie transformacji i globalizacji. Toruń: Wydawnictwo Wyższej Szkoły Bankowej.

Ostry, S, (2001). Globalisation and Sovereignty. Montreal: McGill University.

Stonehouse, G. Hamill, J. Campbell, D. Purdie, T. (2001). Globalizacja. Strategie i zarzadzanie. Warszawa: Wydawnictwo Felberg SJA.

Strategor. (1995). Zarządzanie firma. Strategie, struktury, decyzje, tożsamość. Warszawa: Wydawnictwo PWE.

Toffler, A. (1999). Szok przyszłości. Warszawa: Wydawnictwo PWE.

Zorska, A. (1998). Ku globalizacji. Przemiany w korporacjach transnarodowych $i$ w gospodarce światowej. Warszawa: Wydawnictwo Naukowe PWN.

Piotr Maśloch, dr inż., Wyższa Szkoła Bankowa w Toruniu, Katedra Zarządzania.

Jego zainteresowania naukowe koncentrują się na problemach związanych z procesami współczesnej globalizacji i rozwojem gospodarki w warunkach kryzysu.

Piotr Maśloch, his scientific interests are concentrated on the problems of globalization processes and market development in crisis.

adres/address: Wyższa Szkoła Bankowa w Toruniu,

Katedra Zarządzania, ul. Młodzieżowa 31A

87-100 Toruń, Polska

e-mail: pmasloch@wp.pl 